\title{
Sociological Foundation of Pancasila Education as the Original Identity of Indonesian Society
}

\author{
Aris Saputro \\ Department of Pancasila and Citizenship Education, Faculty of Science \\ State University of Malang, Indonesia \\ arissaputro476@gmail.com
}

\begin{abstract}
The purpose of writing this article is to understand the sociological foundation of Pancasila education as the original identity of Indonesian society. A sociological foundation is a foundation that relies on the interaction between individuals with fundamental values in society. Pancasila is described as the norm of ethics because based on Pancasila are moral values. This type of research uses qualitative description. The results of the discussion on the sociological basis of Pancasila education as the original identity of Indonesian society is the basis of a basic or focused explanation contained on an aspect of social sciences that teaches about the values of Pancasila that live and develop in local wisdom customs in Indonesia. Conclusion The sociological foundation of Pancasila as the traditional identity of Indonesian society is Pancasila a formulation of values rooted in the value of values contained and derived from various values in the ethnic group in Indonesia.
\end{abstract}

Keywords: Sociology Foundation; Pancasila Education; Indigenous Tradition Identity

\begin{abstract}
Abstrak. Tujuan dari penulisan artikel ini adalah memahami landasan sosiologis pendidikan Pancasila sebagai identitas asli masyarakat Indonesia. Landasan sosiologis merupakan landasan yang bertumpu pada interaksi antar individu satu dengan lainnya dengan nilai-nilai yang fundamental dalam masyarakat. Pancasila dijabarkan sebagai norma etik karena pada dasar Pancasila adalah nilai-nilai moral. Jenis Penelitian ini menggunakan deskripstif kualitatif. Hasil pembahasan pada landasan sosiologis pendidikan Pancasila sebagai identitas asli masyarakat Indonesia yaitu landasan sebuah dasar atau tumpuan penjelasan yang terkandung mengenai suatu aspek ilmu sosial yang mengajarkan tentang nilai-nilai pada Pancasila yang hidup dan berkembang dalam kearifan lokal adat istiadat di Indonesia. Kesimpulan Landasan sosiologis yang berjiwa Pancasila sebagai identitas tradisi masyarakat Indonesia adalah Pancasila sebuah rumusan nilai-nilai yang berakar dalam penghayatan nilai yang terkandung dan berasal dari berbagai nilai pada suku bangsa di Indonesia.
\end{abstract}

Kata Kunci: Landasan Sosiologi; Pendidikan Pancasila; Identitas Tradisi Masyarakat Asli 


\section{INTRODUCTION}

Pancasila is the source of all legal resources in Indonesia (Kurnisar, 2020). Pancasila is the basis of the Indonesian state that will not be denied. But Pancasila in the Reformation era of 1998 seemed to "sink" into a vortex of history that was no longer relevant to be included in dialectics. At that time Pancasila was increasingly rarely spoken, discussed, quoted especially applied both in the context of the life of the state, nationality and to the layers of society. In the Reformation era, the context of democracy and political freedom, teaching, discussion, and socialization of Pancasila was limited and "buried" amidst the frenzy of the democratic agenda of the Government of the Republic of Indonesia.

The dynamics of society and nationhood in life will not be separated from the sociological foundation of Pancasila. Social sensitivity in every human being is seen by being constructed by society (Wijaya 2016). The sociological foundation of Pancasila excavated in society is still not touched too much. Revitalization is necessary sufficient to be explored into something more interesting and relevant. This needs to be excavated because the era is constantly moving and now it has entered the digital era and new media (Hendar, 2016).

Sociological studies on education in principle cover all educational pathways, both school education, and non-school education.
The process of socialization of Pancasila education began from the family by introducing Pancasila in everyday life. Article 1 number 10 of the Law of the Republic of Indonesia Number 20 the year 2003 concerning the National Education System (UU Sisdiknas), that is: "The education unit is an educational services group that organizes education on formal, non-formal, and informal lines at every level and type of education."

Informal education services are also regulated in Article 1 number 13 of the Sisdiknas Law, namely: "Informal education is a pathway to family and environmental education." Informal education determines a child's personality before the formal school process.

The education process is also heavily influenced by various social groups in the community such as religious groups, youth and scout organizations, and others. Social influences that affect children include one specific group that comes not from adults, but from other children who are almost the same age called the peer group (Umar, 2005).

Another important role is the influence of education on society. Aspects that can be used as a learning media of social change are social change itself, forms of social change, social change processes, and channels used to make social changes (Nursafitri et al. 2020). Social change to the influence of education is a classic issue that has been studied since time immemorial. The problem is related to the 
sociological foundation of Pancasila education that needs to be specially emphasized on all elements in extracting the original identity of multicultural Indonesian society. Education is a provision to prepare children to live in the community (emphasis on socialization) and prepare children to revitalize the pattern of community life (emphasis on renewal agents). The purpose of this writing is to understand the sociological foundation of Pancasila education and explore sociological values as the original identity of Indonesian society. By summarizing all aspects of sociological foundations containing explanations of theories in society and methods of education Pancasila becomes more interesting and relevant for children. Related to all the things described above, the author will spell out the thoughts by discussing comprehensively in this article with the title "Sociological Foundation of Pancasila Education as the Original Identity of Indonesian Society".

\section{RESEARCH METHODS}

The method used to solve this research problem is using the descriptive qualitative research method. The qualitative method is used to obtain in-depth data, data containing meaning. Meaning is the actual data, the data is certain and is a value behind the visible thing. So in qualitative research does not emphasize generalization, but rather the value of meaning (Sugiyono, 2014).

\section{DISCUSSION}

Based on the problems and the excavation of values in this research, it will be discussed related to the sociological foundation of Pancasila education and the elaboration related to the traditions of the indigenous identity of Indonesian society by Pancasila analyzed with the theory of evolution.

\section{Sociological Foundation of Pancasila Education}

The runway comes from the word "takeoff" which means "pedestal or pedestal" (KLBI, 2003). Lexically, the foundation means the pedestal, the base, or the base, because the foundation is a resting place or a starting point or the base of the (Sulipan, 2009). Sociology itself comes from the creation of the Count or rather Auguste Comte (1798-1857) is a combination of the Roman word socius and the Greek word logos. Coser recounted that the Count originally intended to give the name social physics to the science he was going to create, but later abandoned his intentions because the term had been used by another character, Saint Simon, which eventually used the term (Kamanto, 2004).

Sociology of education comes from two words, namely sociology and education. Sociological etymology comes from the Latin/Roman word socius meaning "comrade" and the Greek word logos meaning "word" or "to speak" (Soerjono, 1986). Education itself 
comes from the Greek pedagogies which means guidance given to children (Padil, 2010). The definition of 'education' is the process of changing the attitudes and behaviors of a person or group to humanize people through teaching and training (Damsar, 2011).

Sociology of education emphasizes the social implications and consequences of education and looks at educational issues from the point of the social and cultural, political, and economic totality of society (Suhada 2020).

Experts have contributed to his thinking, especially in defining the sociology of education. Here are some definitions of expert opinion:1) Ellwood. Sociology of education is a science that learns about the meaning of the relationships between all the main problems between the educational process and the social process. 2) FG. Robbin and Brown. Sociology of education is the science that discusses and explains social relationships that influence individuals to gain and organize experiences. Sociology of education studies social behavior and the principles of controlling it (Padil, 2010). 3) Zainuddin Maliki, understands terminologically that the sociology of education is the study of how institutions and social forces affect the processes and outcomes of education and vice versa (Zainuddin, 2008:5). 4) Menurut S. Nasution, sociology of education is a science that seeks to know ways of controlling the educational process to develop the personality of the individual for the better (S.Nasution, 2010). This definition explains that education itself is a social activity to print a generation that has a good personality, character, and morals. 5) Abdullah Idi defines the sociology of education as a science that describes and describes institutions, social groups, social processes, where there is a social relationship with that social interaction the individual acquires and organizes his/her experience (Abdullah, 2011). Thus, it is concluded that the so-called sociology of education is a science that studies educational problems and tries to find solutions based on sociological approaches. Sociology of education is a scientific analysis of social processes and patterns of social interaction in the education system.

The sociological foundation of Pancasila education can not be separated from the theory of evolution that shaped it. The theory of evolution was the earliest in sociology and was initiated by Auguste Comte and Herbert Spenser. This theory provides a description that human society develops and grows and describes human thinking developing. Evolution goes through different cycles but no common process affects the whole society equally (George \& Douglas, 2014).

The theory of evolution gives the spirit that the education system in Indonesia can not be separated from Pancasila. Cooperation 
between parents, communities, schools, and the government is to teach socio-cultural based on Pancasila (M.Si 2018). The meaning of Pancasila etymologically in Sanskrit has two kinds of lexical meanings, namely: "panca" means five, and "syiila" means the regulation of good behavior. These words in Indonesian, especially Javanese, are defined as "moral" which has a relationship with morality. Therefore etymologically the word "Pancasila" is intended to be the term "Panca Syiila" which has the lexical meaning of "rocky joints five or the basis of which has five elements". The term Panca Syiila with the letter Dewanagari means 5 (five) important rules of conduct. Pancasila as a way of life becomes a guide for the Indonesian nation in everyday life (Suparlan, 2016).

In the presentation of the above discussion, it can be concluded that the sociological basis of Pancasila education is a basic or focused explanation of a thing seen from aspects of social sciences related to teaching about the values contained in Pancasila, especially disseminating it through education.

The basis of the sociology of education is a set of assumptions that serve as a starting point in the framework of practice and/or educational studies derived from sociology (n.d.). Exploring the values of Pancasila in the life of society, especially disseminating it through education is an appropriate step. On educational values, there needs to be religious habituation applied and ingrained in to create and foster social care, help help, tolerant, responsible, sincere, and high religiosity (Saputri 2020). If the value is not in line with the factors from within, then it is difficult to identify effective support in creating trust and form of social capital (Fortunato 2015). Education makes it possible to influence social networks and access to information that is a key pillar of government (Kamim, Amal, and Khandiq 2019).

Pancasila is described as the norm of ethics because based on Pancasila are moral values. Thus, Pancasila becomes a kind of ethical behavior to the organizers of the state and society of Indonesia to align with the normative values of Pancasila itself.

\section{Traditions of Indigenous Identity of Indonesian People}

The soul of Pancasila is an extract derived from the values contained and derived from various values in the ethnic groups in Indonesia. Pancasila is a formulation of values rooted in the dreaming of Indonesian society. Pancasila is the essence of the abstract and explicit form of the wealth of local wisdom of various ethnic groups in Indonesia.

Indonesian people have the values contained in it. Value is something abstract and cannot be seen, felt, or felt and has no scope. Value is closely related to complex human understanding and activity that is difficult to determine (Djamal 2017). 
Pancasila is not an import ideology that is forced authoritarian to live in Indonesia. On the contrary, Pancasila is excavated from the richness of culture and local wisdom that thrives in the archipelago (Frans, 1992). Pancasila is the soul and life in the sanubari of the Indonesian nation. This confirms that the five principles of Pancasila as enshrined in the Preambule of the Constitution of the Republic of Indonesia Year 1945 (UUD NRI Tahun 1945 ) is the knot of the personality of the Indonesian nation whose content and meaning is ingrained and can be found in local customs, tribes, and cultures. Culture is a fundamental continuation in the management of identity and reputation (Hadiprabuono 2020).

The Indonesian nation is a multiethnic nation with a large number of tribal ethics and the diversity of Indonesian society is inseparable from the variety of traditions that exist (Anon n.d.). The tradition or routine of community action is a socio-cultural reality that can be seen from sociological and anthropological analysis (Sofyan 2020). Thus, below will be described in depth the attachment of ethnic values with the original traditions of The People of Indonesia, as follows:
The Value of the One True God in The Understanding of the Concept of Mulajadi Na Bolon Tradition of the Batak Toba People and the Concept of Opo Wailan Tradition in the Minahasa Tribe

One of the sila in Batak Toba people that is inherent in life is about Mulajadi $\mathrm{Na}$ Bolon (The Great Origin) is the belief in the absolute ruler that makes the universe the basis of all activities and actions carried out by the Batak Toba people either in personal or joint terms. Nuances of Mulajadi Na Bolon's involvement were also found in the cooperation system at open meetings, as well as the taste and social action in the form of Tumpak for traditional parties and Ilu Manetek for the grieving, respect for the elderly, the construction of monuments and so on (Armada, 2015).

\section{The Value of a Just and Civilized Humanity} in the Concept of Mustika Puraga Jati Sunda Tradition in Sundanese People

The second syllabus is a Just and Civilized Humanity. The value that can be excavated is found in the values that live in the Sundanese tribe, namely the matter of the contents of the essay on "Mustika Puraga Jati Sunda", it is explained that this contextual processing results in deep thinking about how fundamental the awareness of human selfpower is in the context of corative relationships between humans. Interaction 
between people and individuals is a form of upholding true human values (Armada, 2015).

The Value of Indonesian Unity in the Concept of Ain Ni Ain Tradition in the Kei People, Maluku Islands

The third principle of Pancasila is the Unity of Indonesia. The value of this third sila is also taken from the dream of the Kei people in the Maluku Islands. In the Kei tribe, there is an understanding that Ain $\mathrm{Ni}$ Ain has the essence that self and others are considered as family, society is synonymous with kinship or kinship.

Kei people understand that family is not limited to batih family (Father-MotherSon) but always the extended family that includes family from Mother clan and Dad family. From this, it can be traced that the meaning of unity has become a value that exists in the people of the archipelago that is ultimately poured on the principles of Pancasila (Kudubun 2016).

\section{People's Values Led by Wisdom of Wisdom in Deliberation/Representation in} Kombongan Tradition There's a Toraja People

The fourth principle of Pancasila is the People Led by Wisdom of Wisdom in Deliberation / Representation. The fourth sila also underlies the values contained in the tradition of deliberation of the Toraja people. The tradition of deliberation of the Toraja people is commonly called Kombongan Ada' by expressing the meaning of the fourth principle of Pancasila that is lived and lived by the Toraja people.

The wheels of government and solving the problems faced by the Indigenous Peoples of Toraja are solved with Kombongan Ada' (Adat Deliberation). Based on the value of the fourth principle in Pancasila is very well lived on the value of tradition that applies to the Toraja people who have been around for a long time and live in the social life of the community (Lura and Sampeasang 2018).

The Value of Social Justice for All Indonesians in the Concept of Memayu Hayuning Bawono Tradition in Javanese People

The formulation of values in the fifth Sila is Social Justice for All Indonesian People. Pancasila gives an articulation meaning of the terminology "whole". In this context, local Javanese wisdom present brings the concept of Memayu Hayuning Bawono (beautifying the universe system) has relevance to the concept of fairness for the Indonesian nation as a whole.

The implementation is real and has a deep connection with the concept of Memayu Hayuning Bawono which has been firmly held in the philosophy and tradition of Javanese society. Indirectly, the values of Pancasila itself have been attached to the fundamental essence of being a Javanese human being who 
is a Menjawani or whole. In the end one cannot ignore that being a Javanese man, then indirectly has become a Pancasilaist human being. This is because the two are correlated (Armada, 2015).

\section{CONCLUSION}

The sociological foundation of Pancasila as the traditional identity of Indonesian society is Pancasila, a formulation of values rooted in the value of values contained and derived from various values in the ethnic group in Indonesia. The values contained in it contain five values in Pancasila, including 1) The value of the One True God in the understanding of the concept of tradition Mulajadi Na Bolon Batak Toba people and the Concept of Opo Wailan tradition in the Minahasa Tribe. 2) The Value of a Just and Civilized Humanity on the concept of Sundanese Teak Mustika Puraga tradition in Sundanese Tribal communities. 3) The value of Indonesian Unity in the concept of Ain $\mathrm{Ni}$ Ain Tradition in the Kei Tribal community, Maluku Islands. 4) The Values of The People Led by Wisdom of Wisdom in Consultative/Representative in the Tradition of the Kombongan Ada' Toraja Tribal community. 5) The value of Social Justice for all Indonesians in the concept of the tradition of Memayu Hayuning Bawono in Javanese Tribal communities.

\section{REFERENCES}

[1] Abdullah Idi. (2011). Sosiologi Pendidikan: Individu, Masyarakat, dan Pendidikan. Jakarta: Rajawali Press.

[2] Anon. n.d. "PERGESERAN TRADISI NGAYAH DALAM KEHIDUPAN MASYARAKAT DI BANJAR DAUH RURUNG, DESA BELALANG, KECAMATAN KEDIRI, TABANAN | JURNAL ILMIAH SOSIOLOGI (SOROT)."

[3] Djamal, Samhi Muawan. 2017. "Pelaksanaan Nilai-Nilai Ajaran Islam Dalam Kehidupan Masyarakat Di Desa Garuntungan Kecamatan Kindang Kabupaten Bulukumba." Jurnal Adabiyah 17(2):161-79. doi: 10.24252/JAd.v17i1i2a5.

[4] Fortunato, Piergiuseppe. 2015. "Democratic Government and Development: A Survey." Asian Development Review 32(2):153-77.

[5] George Ritzer \& Douglas J.Goodman. (2014). Teori Sosiologi. Bantul: Kreasi Wacana.

[6] Hadiprabuono, Bayundaru. 2020. "SRAWUNG: IMPLEMENTASI BUDAYA PERUSAHAAN DALAM PENGELOLAAN KEDAI KOPI DI MAGISTRA COFFEE YOGYAKARTA." Jurnal Sosiologi Nusantara 6(2):103-22. doi: 10.33369/jsn.6.2.103-122.

[7] Kamim, Anggalih Bayu Muh, Ichlasul Amal, and M. Rusmul Khandiq. 2019. "PEMERINTAH SEBAGAI AGEN PERUBAHAN SOSIAL YANG DIRENCANAKAN: STUDI ATAS PEMBANGUNAN KEMARITIMAN DAERAH ISTIMEWA YOGYAKARTA." Dialektika Masyarakat: Jurnal Sosiologi 2(2):95-120.

[8] Kudubun, Elly Esra. 2016. “AIN NI AIN: Kajian Sosio-Kultural Masyarakat Kei Tentang Konsep Hidup Bersama Dalam Perbedaan." Cakrawala 5(2). 
[9] Kurnisar, Kurnisar. 2020. "PANCASILA SUMBER DARI SEGALA SUMBER HUKUM DI INDONESIA." Media Komunikasi FPIPS 10(2). doi: 10.23887/mkfis.v10i2.467.

[10] Lura, Hans, and Agustinus Karurukan Sampeasang. 2018. "PLURALISME DAN INTEGRASI SOSIAL." Kinaa Jurnal Teologi 4(1):1-16.

[11] M.Si, Ismail. 2018. "PENTINGNYA SOSIALISASI BAGI ANAK (STUDI KAJIAN SOSIOLOGI PENDIDIKAN)." IJTIMAIYAH Jurnal Ilmu Sosial Dan Budaya 2(1).

[12] Nursafitri, Heni, Heni Nursafitri, I. Made Pageh, and I. Gusti Made Arya Suta Wirawan. 2020. "PERUBAHAN SOSIAL MASYARAKAT SUKU OSING DI DESA KEMIREN SEBAGAI MEDIA PEBELAJARAN SOSIOLOGI." Jurnal Pendidikan Sosiologi Undiksha 2(3):180-89. doi: 10.23887/jpsu.v2i3.28957.

[13] Saputri, Rima $\quad$ Yuni. 2020. "IMPLEMENTASI LANDASAN SOSIOLOGIS DALAM PENGEMBANGAN KURIKULUM MUATAN LOKAL BERBASIS KEAGAMAAN DI SMAN 1 PLERET BANTUL." JURNAL PENDIDIKAN ISLAM AL-ILMI 3(2). doi: 10.32529/alilmi.v3i2.696.

[14] Sofyan, M. Ali. 2020. "EKSISTENSI MEGONO SEBAGAI IDENTITAS KULTURAL: Sebuah Kajian Antropologi Kuliner Dalam Dinamika Variasi Makanan Global." Jurnal Sosiologi Reflektif 15(1):4562. doi: 10.14421/jsr.v15i1.1751.

[15] Suhada, Suhada. 2020. "SOSIOLOGI PENDIDIKAN DALAM PEMBENTUKAN KARAKTER (Sudut Pandang Sosial)." $A l$ Amin: Jurnal Kajian Ilmu dan Budaya Islam 3(1):113-21. doi: 10.36670/alamin.v3i1.44.
[16] Syatriadin. n.d. "LANDASAN SOSIOLOGIS DALAM PENDIDIKAN | Satriadin | JISIP (Jurnal Ilmu Sosial Dan Pendidikan)." Retrieved January 9, 2021 (http://ejournal.mandalanursa.org/index.php/ JISIP/article/view/171/162).

[17] Soerjono Soekanto. (1986). Sosiologi Suatu Pengantar. Jakarta: Radar Jaya Offset.

[18] Sugiyono. (2014). Memahami Penelitian Kualitatif. Bandung: ALFABETA.

[19] Sulipan. (2020). htttp://wordpres.com/2009/10/02/pengertiandan-jenis-landasan-pendidikan/, diakses tanggal 20-10-2020, Pukul: 19.00.

[20] Suparlan. (2016). Peran Pendidikan dalam Era Global. Bandung: Alumni.

[21] S. Nasution. (2010). Sosiologi Pendidikan. Jakarta: Bumi Aksara.

[22] Umar Tirta Rahardja dan S.L. La Sulo. (2005). Pengantar Pendidikan, Jakarta: PT Rineka Cipta.

[23] Undang-Undang Republik Indonesia Nomor 20 Tahun 2003 tentang Sistem Pendidikan Nasional.

[24] Undang-Undang Dasar Negara Republik Indonesia Tahun 1945.

[25] Wijaya, Daya Negri. 2016. "Kontrak Sosial Menurut Thomas Hobbes Dan John Locke." Jurnal Sosiologi Pendidikan Humanis 1(2):183-93.

[26] Zainuddin Maliki. (2008). Sosiologi Pendidikan. Yogyakarta: Gadjah Mada University Press. 